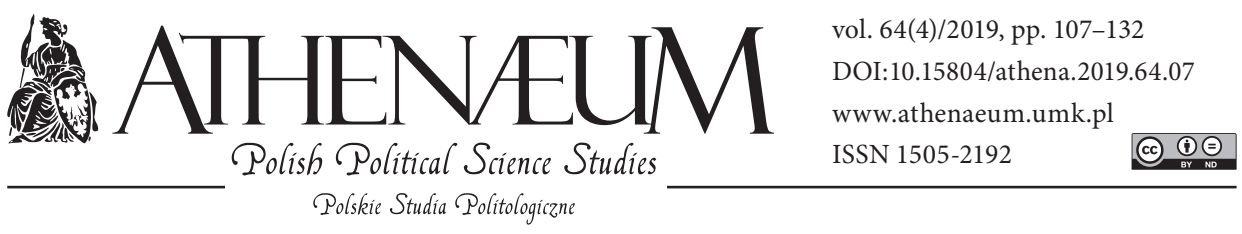

\title{
THE CONSTRUCTIVIST APPROACH TO EUROPEANISATION AD PERSONAM: TOWARDS SOCIAL FUNCTIONALISM
}

\author{
PODEJŚCIE KONSTRUKTYWISTYCZNE DO EUROPEIZACJI
} AD PERSONAM. W KIERUNKU SOCJOFUNKCJONALIZMU

Janusz Ruszkowski*

\begin{abstract}
Europeanisation is a process, but theory of Europeanisation is a theory of impact and influence configured as a feedback between the EU and its member states, as well as international organisations, third states, and furthermore, between the $\mathrm{EU}$ and persons (both citizens of the EU and the citizens of the states outside of the EU).

In researching the impact of European integration (and the EU itself) on specific persons, one should note that, for instance, Europeanisation of the Council of the EU officials is neither top-down nor bottom-up Europeanisation, nor is it ad extra or ad intra one. The purpose of this article is to sequentially examine only one type of Europeanisation, namely ad personam (EAP), with the use of tools applied in constructivism. The study of ad personam Europeanisation is conducted here on the example of the Council of the European Union (CEU) officials.
\end{abstract}

Keywords: Europeanisation; theory of European studies; constructivism; social functionalism
Europeizacja jest procesem, ale teoria europeizacji jest teorią wpływu rozumianą jako sprzężenie zwrotne pomiędzy Unią Europejską a jej krajami członkowskimi oraz organizacjami międzynarodowymi i państwami trzecimi, a ponadto pomiędzy UE a osobami (zarówno obywatelami UE, jak i obywatelami krajów spoza UE).

W badaniu wpływu integracji europejskiej (w tym Unii Europejskiej) na osoby (tutaj przede wszystkim na urzędników Rady Unii Europejskiej) powinno się zauważyć, że nie jest to europeizacja top down ani europeizacja bottom up, zresztą nie jest to także europeizacja ad extra ani ad intra. Celem tego artykułu jest zbadanie tylko jednego typu europeizacji, którym jest europeizacja ad personam (EAP), przy użyciu narzędzi należących do teorii konstruktywizmu.

Słowa kluczowe: europeizacja; teoria studiów europejskich; konstruktywizm; socjofunkcjonalizm

\footnotetext{
* University of Szczecin, Faculty of Humanities.
} 


\section{METHODOLOGICAL ASSUMPTIONS}

Even a preliminary research on categories and definitions of the core meaning of Europeanisation justify the constructivist approach to processes of Europeanisation. In theoretical approaches to Europeanisation some findings and categories recur (Graziano \& Vink, 2007; Ladrech, 1994; Radaelli, 2003; Risse, Cowles, \& Caporaso, 2001; Bache \& Marshall, 2004). First of all, Europeanisation is a process. Secondly, it consists in affecting and exerting influence. Thirdly, it is conducive to a transference of elements of institutional culture (including the culture of responsibility), which contains norms, patterns, rules, standards, values, principles, actions, procedures, obligations, behaviours (styles of behaviour), common beliefs, interests, and information ${ }^{1}$. Next, it anticipates implementation of the elements of institutional culture. Finally, it creates a noticeable effect. It seems that these are the main categories of Europeanisation, which may be understood as "hard", in other words, essential to this approach and necessary for the analysis. It is therefore worthwhile to consider what constructivism might bring to the study of Europeanisation. Even this short list of "hard" categories of Europeanisation seem to show that in this research it is advisable to at least experiment with constructivist tools. This concerns mainly such categories as "influence" (impact) and "transfer", as well as implementation of elements of institutional culture, especially those which have ideational features (patterns, values, norms, obligations), but also others, which might be ideational to some extent (rules, standards, principles).

What is more, two other categories should not be omitted, as they have important explanatory function in research on Europeanisation. These are, namely, "reference points" (référentiel), and “the bandwagon effect”. „Reference point” is considered by the researchers of Europeanisation processes, as it concerns initial contextual conditions (structure) from which the process of Europeanisation starts, and which has the power of influence. Internal (normative) "culture" of a given institution, the European Union legal system, or, for instance, the value system of the EU, may be the reference point. On the other hand, "the bandwagon

1 In this case, the institutional "hard reality" is linked to such elements of internal culture of a given institution. What should be understood as "internal culture of an institution" (or "internal institutional culture") is a widely understood political, legal, informational, axiological and personal reality and ideation, attesting to the identity of the given institution (and distinguishing this institution from others), comprised of many elements (e.g., norms, patterns, rules, standards, values, principles, actions, procedures, obligations, behaviours, information, and so on). 
effect" is one of the most crucial end results of the influence of Europeanisation processes. It constitutes an absorption, and then regular replication of transferred elements (values, norms, regulations, and so on) of the institutional culture (including the culture of responsibility). There are three types of replication: full, selective, and contextual one. The full replication is a reflection of all transferred models, while selective replication consists in exclusionary mimicry of transferred models, depending on ability or will. Finally, the contextual replication is a non-recurring mimicry of given behaviour or model, which only takes place in a (single) specific case.

Researching Europeanisation processes with the use of constructivist tools is a measure which requires many tests and attempts to find mutual connections between these two theoretical approaches (on the condition that Europeanisation may be considered a theory, e.g., a specialist one (Ruszkowski, 2012, p. 17), or in a narrower sense, between its components, i.e., tools and categories).

The purpose of this article is to sequentially examine only one type of Europeanisation, namely, ad personam (EAP), with the use of tools applied in constructivism. The study of ad personam Europeanisation is conducted here on the example of the Council of the European Union (CEU) officials². The Council, like any institution, is characterized by its particular institutional culture and, as predicted by constructivism, is both connected to and constituted by a wide social environment (Jepperson, 2001, p. 6; Ruszkowski, 2013a, pp. 9-27, 2010, p. 41). Thereby, the CEU is, on the one hand, the Europeanizing reference point (référentiel), and on the other, it possesses a large dose of constructivist naturalness, which makes the processes affecting the subjects operating within the CEU also socially natural. If to a socially generated institution its soft understanding, which dominates in constructivism, is added (e.g., via ideas, social and cultural norms, regulations and routines of behaviour and actions which apply in the $\mathrm{CEU}$ ), then human interactions will be the source of norms, which create normative environment and in fact have a strong influence. Therefore, an institution such as the CEU, even if it obviously impacts the actors' actions, is not the only one to do so.

2 In this article the term "official" is used, as the term "officer" would be imprecise, suggesting that the person is employed full-time in the internal structures of the Council. However, the CEU, besides the actual full-time employees, includes also the ambassadors of the member states or their deputies, in both COREPERs, as well as ministers of the state members in the compositions of the Council who are not its full-time employees. 
Europeanisation of the CEU officials is unusual, as so far none of the known trajectories of Europeanisation can effectively explain a direct influence of the European integration on persons (including the officials operating in the EU institutions). For this reason then, the author of this article first searches for a trajectory of Europeanisation which is more adequate to his research objectives. Subsequently, such Europeanisation is explained with the use of two fundamental tools of constructivism: the logic of appropriateness and socialisation. Finally, the constitutive features of the constructivist process of socialisation are mixed with their neofunctionalist equivalents (which are classic in European studies), in order to examine if such a procedure might provide an explanation for the Europeanisation process in persons.

\section{EUROPEANISATION AD PERSONAM IN EUROPEANISATION STUDIES}

Theory of Europeanisation ${ }^{3}$ is a theory of impact and influence configured as a feedback between the EU and its member states, as well as international organisations, third states, and between the EU and persons (both citizens of the EU and the citizens of the states outside of the EU) (Levi-Faur, 2007, p. 102)4. Europeanisation, affecting, for instance, states and regions, also impacts people, hence its evident sociological inspirations and aspirations.

The process of Europeanisation has two inner trajectories (within the EU) and two outer ones (outside of the EU). The first inner trajectory is described as top-down Europeanisation, and it consists in “downloading” European political and legal models as well as values to the political systems of the EU member states or states outside of the EU (input effect), with impact on the domestic inter-institutional relations (Bursens, 2007, p. 118). In this way, the political, legal and economic dynamics of the EU becomes a part of the state politics (Ladrech,

3 Europeanisation may be defined depending on its wider or narrower understanding. Europeanisation sensu largo is the impact of Europe as a historical, cultural, social and institutional whole, while Europeanisation sensu stricto is limited to the European Union only, therefore also called 'EU-isation'. This article will focus on the latter, narrower sense.

4 D. Levi-Faur introduces several research postulates into current studies on Europeanisation. According to Levi-Faur, what shall constitute a significant challenge for scholars of Europeanisation is a comparative analysis, founded on three redeployments: 1) from the government to the governance; 2) from national levels to regional or global levels; 3 ) from a unitary state to a disaggregated state. 
1999, p. 71). Such a model is based on an export (transfer) of European solutions to states' political systems, on which it has a crucial impact. The second inner trajectory is described as bottom-up Europeanisation and denotes the system of internal management of the EU by "uploading" functions, tasks and responsibilities of the member states (or national institutions) onto the European level in order to minimalise the costs of adjustment and harmonisation (output effect) (Bulmer, 2007, p. 48).

According to James Caporaso, the first wave of European integration was

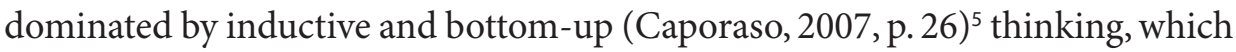
means that initially it was focused on the process "from state and society of the member states to the regional organization", and then from regional organisations towards institutions created within the framework of these organizations, in other words, "from the member states to the centre" (Caporaso, 2007, p. 26).

Besides the aforementioned internal trajectories of Europeanisation, the outer trajectories should be also mentioned. The first one, called Europeanisation ad extra ${ }^{6}$, takes place when solutions, policies and models of operations undertaken in the states outside of the $\mathrm{EU}$ (also on other continents) ${ }^{7}$ are Europeanised. The second trajectory, which is Europeanisation ad intra, takes place when third states determine integrational processes within the EU or apply to use instruments of the EU (financial, political, etc.), by which they mobilize the potential and influence of the EU (Borkowski, 2013, p. 136) ${ }^{8}$.

5 Traditional theories of integration are characterized by the bottom-up analysis. Besides, the literature features an analysis of intra EU, conducive to a comparative examination of political systems and top-down analysis, which should be used in the research of Europeanisation processes.

6 Europeanisation is a process which is not limited to the EU or Europe only (as it has been mentioned already, it is territorialized and multi-directed). The virtues of Europeanisation may be exported outside of the EU, to non-member states in Europe and beyond the European continent, to other regions or to international organisations. Such virtues, although assumed and accepted also outside of Europe, are nevertheless characterized by specifically European spirit. Europeanisation ad extra, or the so-called "outer" or "outside", is therefore another type of Europeanisation which shows the influence of European integration on the integrational relations, organisations, states, regions, etc., beyond Europe. Europeanisation ad extra is a form of an "exporting" of Europeans organizational, normative and axiological models to the outside of the EU.

7 Therefore, a claim that every Europeanisation influences the creation of supranationality is at best common.

8 For instance, in 2004, after the accession of 10 states to the EU, Russia refused to accept the national veterinary certificates of some member states of the EU, demanding unified EU certificates. 
Although Europeanisation is a process with strong sociological features, as by influencing institutions, states and regions, de facto it influences people, yet none of the Europeanisation types mentioned above, either those of inner or outer trajectories ${ }^{9}$, is adequate and, at the same time, useful in research. Looking for an explanation of the situation in which the process of Europeanisation

9 Of course, it is noticeable that there are specific correlations between Europeanisation of inner trajectories and that of outer trajectories. For instance, ad extra and ad intra Europeanisations are outer reflections of top-down and bottom-up trajectories respectively, raising a doubt if demarcating outer trajectories is necessary (while the earlier top-down and bottom-up may be also used to countries outside of the EU). There are, however, several reasons why such a division is advisable. First, outer trajectories specify the impact of Europeanisation by specifying its objects (on the one hand, member states, on the other - third states). Secondly, Europeanisation process with inner trajectories is much more intense and has a bigger power of intervention (impact) than the process of Europeanisation with outer trajectories. Thirdly, Europeanisation with outer trajectories has a wider territorial impact (with a smaller intensity of influence), which makes Europeanisation with inner trajectories more condensed (concentrated), while those with outer trajectories are more diffused. Next, Europeanisation of inner trajectories is de facto the EU-isation, or Europeanisation of integrated Europe (auto-Europeanisation or even meta-Europeanisation), while Europeanisation of outer trajectories may be additionally divided into extra-European, which is an extension of "Europe beyond Europe", and European, which will concern European states which do not belong to the EU (Europeanisation of the non-integrated Europe). Finally, only Europeanisation of inner trajectories may be divided into pre-access and post-access one, while such a division in Europeanisation of outer trajectories (with some exceptions of several associated states which might become members) practically cannot be made. These specific features of both trajectories of Europeanisation compel their clear separation. These are just some important differences which make the division of Europeanisation into inner and outer trajectories necessary, even if both of them share some "family resemblance" (this resemblance, however, concerns only the direction of their influence, or a simplified feedback, from states to the EU and from the EU to the states).

Additionally, existing research justifies demarcation of Europeanisation with outer trajectories, although using Europeanisation inside the EU (EU-isation) does not demand additional explanation, as for many scholars in European studies it is a natural starting point. Of course, this is correct. James Caporaso defines intra EU, which is conducive to comparative studies, at the same time being also conducive to a comparison of Europeanisations of inner trajectories (Caporaso, 2007, p. 26). P. Mazurkiewicz also believes that "Europe is nothing but a constant process of auto-Europeanisation. Europeanisation is an inner process in Europe. This movement indeed constitutes Europe. Europe does not exist prior to Europeanisation. Europe is the result of Europeanisation" (Mazurkiewicz, 2001, p. 17). This is research conducted already in the 21st century. The most recent theoretical approach to Europeanisation is social functionalism (Watanabe, 2010; Olsen, 2002). The research underlines the importance of all effects of Europeanisation, which might be divided into voluntary or imposed, and into intended (consciously planned) and unintended (unplanned and involuntary).

To justify demarcation of Europeanisation with outer trajectories, one should mention, among others, Johan P. Olsen, who remarks that among the potential meanings of the term 'Europeanisation' there is the change and expansion of the outer borders of the EU and export of the political organization model of the EU beyond its borders (Loužek, 2006, p. 184). 
directly affects people, we may notice that the types of Europeanisation processes examined so far do not reflect the essence of this impact. In researching the impact of European integration (and the EU itself) on specific persons, one should note that, for instance, Europeanisation of the Council of the EU officials is neither top-down nor bottom-up Europeanisation, nor is it ad extra or ad intra one. This begs a question, what type of Europeanisation is that which affects the CEU officials (or officials in other institutions of the EU)? There is a possible answer, which leads towards Europeanisation ad personam (EAP) (Ruszkowski, 2013b).

EAP is much more useful and effective in research focused on persons (i.e., officials in European institutions or citizens of the EU, as well as citizens of the third countries), as it constitutes in acquiring European line of action (conversations, deliberations, compromise), and European codes of behaviour and values (solidarity, cooperation, and so on). EAP is therefore the most sociological type of Europeanisation. The enumerated elements may indicate that ad personam Europeanisation is an autonomous trajectory of impact of the European integration (or, to be more precise, of the EU itself), because it is not equivalent to any of the Europeanisation trajectories known so far.

The study of Europeanisation ad personam shows that this process has the strongest and quickest impact on the officials in the EU institutions ${ }^{10}$ (Europeanisation of the first degree, i.e., directed at a subject closest to the centre), then the elites in the member states and widely understood citizens of the $\mathrm{EU}$ (Europeanisation of the second degree); next, persons residing in the EU states but not their citizens (Europeanisation of the third degree); and finally, the slowest and the weakest (if any) impact is had on the citizens of the third states, outside of the EU (Europeanisation of the fourth degree, i.e., concerning the subject most removed from the centre $)^{11}$. Almost identical stratification is

10 In this group one may also distinguish officials of various levels and institutions, which may be correlated with the quality and the effectiveness of their Europeanisation and cause important differences in the impact of this process. These issues are the subject of this article further on, in the subsection concerning the Council of the EU and its multi-level internal structure, which has direct effect on the quality of Europeanisation ad personam of its officials.

11 Gradeability of Europeanisation ad personam is partly correlated to the multi-level approach, as the three degrees of multi-level governance (MLG): supranational (or, more widely understood as Europeans), and national. Obviously, multi-level Europeanization (MLE) is a separate issue to be examined. After all, the fact that ad personam Europeanisation is of a multi-level character is also 
evident also in the Europeanisation of language ${ }^{12}$, which is immanently linked to ad personam Europeanisation. Obviously, the Europeanisation of language of the officials of the EU institutions is the quickest, while that of the third state members is the slowest.

This type of gradeability of ad personam Europeanisation allows to understand the differences in, on the one hand, the impact of this process, and on the other - in the level of its absorption by individuals. Therefore, the institutional environment, its internal culture and normative density are more conducive to Europeanisation ad personam than the wider and less structured environment outside the EU institutions, and even more so the environment outside the EU as such. The environment creates the so-called reference points (référentiel) in the process of ad personam Europeanisation.

Additionally, what takes place in EAP of the first degree is the phenomenon of "learning"13, which is not so often evident in EAP of the second and third degrees. The officials of the given institution "learn" its internal rules, regulations and standards and acquire roles and behaviours observed among other officials. One may venture a claim that they learn the institution in which they work. "Learning" may also take place by means of "imitating" or "mutual learning”.

Interactions on the level of the EU and on the level of its institutions become points of reference for officials of this institution via actions and procedures which modify the behaviour of these officials, or via their acquisition, implementation (in constructivism: internalisation) of institutional models and values, and finally via socialisation. The reference point or reference (référentiel) (Radaelli \& Pasquier, 2007, p. 37), as a term which is considered by ad personam Europeanisation studies, becomes a crucial, if contextual, initial condition for this type of Europeanisation. Europeanisation connected with the quality of institutionalization is very close to constructivist studies, as constructivism is a sociological theory of institutional dynamic, and therefore constitutes

evident in its presence on various levels of the CEU structure (so-called intra-institutional stratification) (Ruszkowski, 2013b, pp. 35-36).

12 What is meant here is not learning foreign languages, but acquiring official and administrative vocabulary, or at times even a whole intra-institutional slang.

13 That is, gradual acquiring and consolidating skills. More on "learning", including "rational learning" characterized by objectivity, which features also in constructivism (Weyland, 2009, p. 397). One may also mention "social learning" (Checkel, 2001, p. 53), or the politics of disseminating knowledge (as well as politics based on knowledge). 
a type of institutionalism, or rather a combination of social institutionalism and structuralism (Trzaskowski, 2005, p. 381). "Constructivism considers the process of institutionalization in categories of 'institutional isomorphism'. Institutionalization is understood as a constraining process, which forces actors or organisations to copy institutional solutions characteristic of other organisations which function in a similar environment. Organisations take shape from other, similar organisations, which are perceived as more successful or more legitimate" (Trzaskowski, 2005, p. 381). Reflective constructivism is focused on interactivity and, above all, on understanding the importance of formal and informal norms.

Studying ad personam Europeanisation with the application of constructivist approach shall be effective depending on how many ideational, identity or, e.g., axiomatic elements may be found in reference points (référentiel) that could be constituted by, e.g., institutions, their internal culture and normative density. What is significant, the reference point is an equally important category in constructivist processes (e.g., socialization) as it is in Europeanisations studies, which makes the point of applying constructivist tools to researching Europeanisation even more compelling.

\section{THE MAIN TOOLS OF CONSTRUCTIVISM APPLIED TO EUROPEANISATION AD PERSONAM. THE LOGIC OF APPROPRIATENESS}

At this point, it is necessary to mention two fundamental principles of constructivism, following Alexander Wendt. According to the first principle, "the structures of human association are determined primarily by shared ideas rather than material forces", while according to the second one, "the identities and interests of purposive actors are constructed by these shared ideas rather than given by nature" (Wendt, 2003, p. 1). These principles also include the foundations of the constructivist logic of appropriateness.

Searching for a connection between ad personam Europeanisation and constructivist socialization should begin from establishing the first factor which influences socialization and its effectiveness, that is, the logic of appropriateness. Defining the logic of appropriateness which organises politics, James G. March and Johan P. Olsen recognised that "political institutions are collections of interrelated rules and routines that define appropriate actions in terms of 
relations between roles and situations. The process involves determining what the situation is, what role is being fulfilled, and what obligations of that role in that situation are. When individuals enter an institution, they try to discover, and are taught, the rules. When they encounter a new situation, they try to associate it with a situation for which rules already exist. Through rules and a logic of appropriateness, political institutions realize both order, stability, and predictability, on the one hand, and flexibility and adaptiveness, on the other" (March \& Olsen, 2010, p. 160). Therefore the „logic of appropriateness” is defined by the values, rules, norms, procedures and activities considered to be internal of a given institution and appropriate and correct for its officials. Undoubtedly, the officials' behaviour in international institutions is gradually rule-governed (North, 1990, p. 42).

Institutional and constructivist behaviour of individuals is shaped by the logic of appropriateness, in turn defined by values (norms, behaviours) considered to be internal for the given institution. The logic of appropriateness dictates to behave according to a given situation and one's role (position, job title, function) and according to the rules binding in a given environment (surroundings) (North, 1990, p. 33). At that point, some obligatory actions take place; however, these are not actions which would result from stable interests or needs. By shaping institutional behaviour, an institution may either limit or enable a political change. In the logic of appropriateness, institutional behaviour is dictated by establishing the parameters of acceptable behaviour (Peters, 1998, p. 8). The logic of appropriateness is a system of internal procedures, activities and values, based on the situation in a given institution, which is its starting point and, at the same time, social environment (in Europeanisation nomenclature it would be called the reference point, référentiel) with specific procedures, norms and values, and which at the same time forces officers who operate in this institution to fulfil specific roles and activities according to values. This kind of institutional culture causes a diffusion of elements of this culture (norms, rules, values), which may lead to it being accepted by the officials, or, in other words, internalisation.

If the official follows the norms and models of a given institution, considering them as their own, it means that the process of internalisation is effective, as it creates specific behaviours. This process is, at the same time, internalisation of norms, values and rules accepted by the officers as those which co-create their institutional identity. 
Following J. Checkel, A. Skolimowska points to two types (stages) of internalisation ${ }^{14}$; the first one is blind internalisation, during which the agents [officials - J.R.] are passively subjected to intersubjective meanings. They adjust their behaviour to new rules by learning their roles and acquiring knowledge, which will enable them to act according to others' expectations. What may also occur here is behaviour according to the logic of consequences ${ }^{15}$, signified by rejecting instrumental calculation in favour of the will to play a specific role in the community. The second type/stage is acceptance of the community and its values by the actor as right and correct. At this stage, the actor accepts interests, or even identity of the community as their own (Skolimowska, 2013, p. 231).

The officials' behaviour according to the logic of appropriateness is dictated by establishing the parameters of acceptable action (Peters, 1998, p. 8) and their ability to adjust to institutional roles. The officials do that following the logic of appropriateness (March \& Olsen, 2010, pp. 166-168) when it comes to their behaviour. The logic of appropriateness requires one to behave according to given situation and one's function (position or job title) (March \& Olsen, 2010, p. 23). Then, some obligatory actions take place, although these are not actions which would result from stable interests or needs. As a result of behaving according to the logic of appropriateness, proper actions take place, or proper roles are played by the officials, adequately to the given institution, while the officials share the values preferred in this institution. The effect of this process is socialisation of people (officials), who, accepting procedures, norms and values of the institution, adjusted their actions and roles to them (see: Figure 1).

14 A. Skolimowska's viewpoint identifies internalisation with socialisation (Skolimowska, 2013). It seems, however, that these two processes are distinct (which is discussed further on in this article). Socialisation, besides internalisation, includes also mimicry and identification. More on the topic, see: Zamęcki, 2011, p. 33.

15 Logic of consequences has rationalist provenance and was already known among functionalists and neofunctionalists. Progressing from the logic of consequences towards logic of appropriateness takes place during the process of learning and mimicry, as shall be discussed further in this article. 


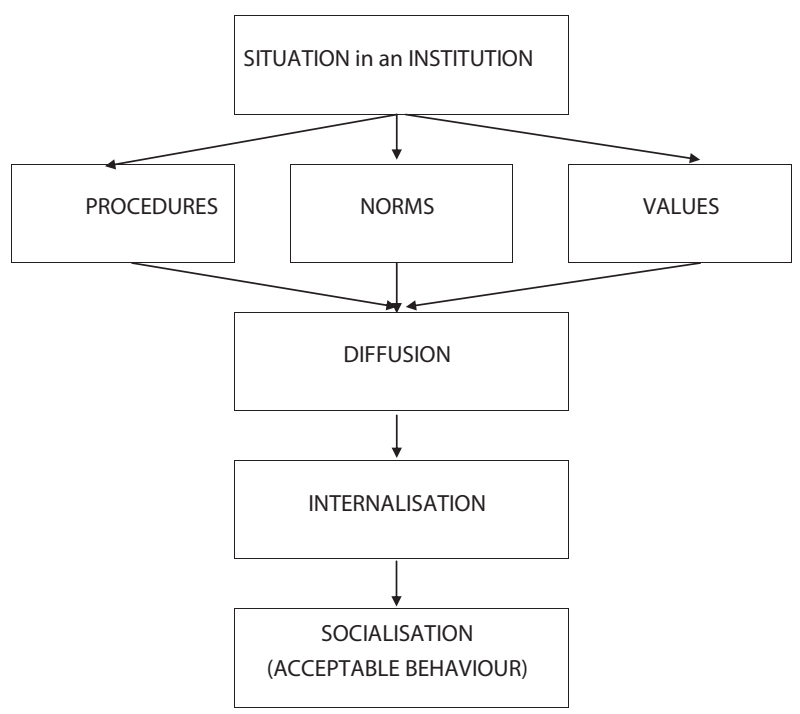

Figure 1. The Process of Socialisation

Source: author's own elaboration.

\section{SOCIALISATION}

Claudio M. Radaelli and Romain Pasquier state that the impact, one of the key phenomena in Europeanisation and an important explanatory category, does not necessarily stand for strong stimulus ${ }^{16}$, but often denotes a subtler influence of socialisation ${ }^{17}$ processes, ideational convergence, learning and interpretation of paradigms and political ideas (Radaelli \& Pasquier, 2007, p. 39; Zamęcki, 2011, p. 33). Those softer features become a matter of a consensus. Such an understanding of the term 'impact' as a key category in Europeanisation is a clear link between Europeanisation and constructivism, and at the same time, it suggests a research method which should not ignore constructivist tools.

In constructivism, following the logic of appropriateness, in other words, behaving according to procedures, norms and values, leads to an internalisa-

16 Here it is necessary to indicate two types of impact in Europeanisation studies: 1) horizontal impact, created as a result of cooperation between member states, where the repertory of Europeanised fields may be widened; 2) vertical impact, created as a result of transposition of elements created in the EU and their implementation on other levels of multi-level governance in the EU.

17 Socialisation is often described as communisation (Parsons, 1964). 
tion of actions, values and roles, and as a result, to socialisation of the officials. Socialisation constitutes acquiring rules, norms, behaviours, values - ideas and identities become a matter of consensus, as the actors internalise them (i.e., consider them to be their own) (Skolimowska, 2013, p. 230). However, first, these procedures, norms, rules, models or values have to be created, so that later the structure (institution) will be able to dictate them to their officials and create internal (within the structure) institutional environment (reference point).

Defining the process of socialisation (on the basis of the logic of appropriateness), including its components, offers a visual such as the one provided in Figure 1.

Three mechanisms leading to socialisation may be established: 1) strategic calculation, where the subjects calculate whether a given behaviour is going to get them social benefits (better status) or material (financial) benefits; 2) role playing, where the subjects cannot participate collaterally in all forms of negotiations and manage every issue, start to use normative models functioning in their environment, which enable and automatise negotiations; 3 ) normative persuasion, where the subjects present arguments and attempt to convince their opponents and their interests and preferences are open to redefinition (Kirpsza, 2014, pp. 88-98; Skolimowska, 2013, p. 232).

Socialisation (and its mechanisms) defined in such a way is important for the staff of the EU institutions in its internal administration system. If we ask officials in the EU institutions where they get their skills, values, information, and so on, we certainly notice that the source of these attributes might be either personal predispositions (e.g., to learning), or social circle, environment, in this case - the institution and its social environment (reference point).

If the officials of the EU change their behaviour within a given institution as a result of many interactions, it means that stable structure of this institution and models produced by it had the largest impact on this change. As a result, individual identity of an official becomes identical to the fragment of a supra-individual structure (Trzebiatowski, 2012) ${ }^{18}$. The officials learned the previously created rules of the institution, acquired and implemented them in their behaviour, thanks to which they gained intellectual, physical and moral

18 These models are, after all, the elements of this structure, so they constituted a pre-socialisational, outer context for the officials. 
qualifications to operate within this institution ${ }^{19}$. New ideas, values and rules developed in the institution may boost standards of behaviour according to the logic of appropriateness and be conductive to quicker "acquisition" of officials.

\section{EUROPEANISATION AD PERSONAM OF THE OFFICIALS IN THE COUNCIL OF THE EU AND CONSTRUCTIVIST SOCIALISATION}

If our reference point becomes the Council of the EU as a social output structure, which constrains and shapes behaviours of individuals, we will notice that the behaviour of its officials depends on the intra-institutional level on which they operate. Using multi-level intra-institutional stratification, we may indicate three internal levels of the CEU: 1) political level, 2) coordinating level, 3) working level (Ruszkowski, 2013b, pp. 35-36). Therefore, the actors adjust to institutional and collective roles that they want to play, depending on the level of operation within the CEU, following the logic of appropriateness in their behaviour.

Ministers related to ten configurations of the EU operate on the political level. Due to the logic of appropriateness, the same representatives of state governments who are intragovernmental actors in their own countries, become extra-governmental actors in the CEU, particularly on the first, political level, and on the third, working level, and are subject to other rules and norms, typical for the new environment. Particularly on the third (working) level, the process of socialisation and Europeanisation of the officials, who may not always be representatives of their governments, might also evoke destatization behaviour, which practically indicates a possibility of separating, to a certain extent, from the country of their origin.

It seems that the main mechanism which leads to socialisations of ministers on the political level, which is the most intergovernmental one in the CEU, is "strategic calculation", that is, behaviour which may benefit their represented national state the most. In the language of Europeanisation it means that the impact of the environment of the Council and its institutional culture is not strong because the ministers are not present in the Council every day, but only during the proceedings in their respective composition, and thus they are relatively immune to the elements of this culture and learn it slowly (or incidentally),

19 Thereby a fragment of the structure, which previously was outer and pre-socialisational, becomes an inner part of the officials. 
as they are strongly politicised, therefore their absorption ability is not high. As a result, Europeanisation (ad personam) of ministers on the political level is weak (Ruszkowski, 2014, p. 111) ${ }^{20}$, and mimicry in their behaviour is situational, that is, takes place only in specific situations (e.g., when approving a legal act).

The deputy heads of representatives of the state members in the European Union (in COREPER I) and heads of permanent representatives of the members states in the EU, usually as ambassadors (in COREPER II) operate on the second, coordinating level of the Council. The mechanism which leads to socialisation of the officials on the level of the CEU is normative persuasion, with features of subjectivity, which is behaviour consisting in presenting arguments and convincing other officials to accept them, with everyone's readiness to redefine (or even abandon when persuaded) one's interests and preferences. In the language of ad personam Europeanisation, it means that there is noticeable impact of the environment of the Council and its institutional culture on the officials (who are permanently located in Brussels and meet more often than ministers), and the absorption of the elements of this culture is partial (as diplomats operating on this level are still representatives of their national states), yet the Europeanisation effect is evident (due to the fact that, among other things, diplomats are less politicised than ministers) (Ruszkowski, 2014, p. 111). On this level, the mimicry, learning the institution and its language are selective, which is the result of the specificity of working in CORPERs, which means that diplomats copy mainly these behaviours and activities which are indispensable for effective performance of tasks.

Finally, in the third, working level, the experts (specialists, professionals) are located in working teams and committees as well as ordinary and treaty committees of the Council. The fundamental legislative work happens on this level; legislative records are born here, which later are moved to the coordinating level (to COREPERs) or, in some cases, omitting the coordinating level straight to the political level (this concerns only six treaty committees, allowed for in the primary law). The latter type of direct interaction between working and political levels is an example of bypassing the coordinating level (Ruszkowski, 2014).

The mechanism of socialisation, which affects the officials in these committees is role playing. The officials in the treaty committees are more strongly impacted by it, as these committees are outside the control ${ }^{21}$ of COREPER, and

20 This also concerns Europeanisation of nomenclature.

21 The phenomenon of being outside the control of the supervisor is known in Principal-Agent Theory. For more information, see: Ruszkowski, 2010a, 2008. 
therefore more independent. The mechanism of role playing involves the officials following the models operative in the CEU, thus the roles played are considered proper and right in this environment and fulfil expectations. In the language of Europeanisation it means that acquiring (implementation) of the elements of the institutional culture is effective, learning the internal institutional culture (as well as the culture of responsibility) is fast and continuous (which results from the long stay of the officials in Brussels) and the mimicry effect is full, which means that Europeanisation is strong (this concerns also the official language) ${ }^{22}$.

Table 1. Mechanisms of Socialisation on Particular Levels within the CEU

\begin{tabular}{|l|l|l|l|}
\hline $\begin{array}{c}\text { Levels of management } \\
\text { in the CEU }\end{array}$ & Structure of the Council & \multicolumn{1}{|c|}{ Officials } & \multicolumn{1}{|c|}{$\begin{array}{c}\text { Socialisation } \\
\text { mechanism }\end{array}$} \\
\hline Level I - political & $\begin{array}{l}\text { compositions of the } \\
\text { Council }\end{array}$ & ministers & strategic calculation \\
\hline Level II - coordinating & COREPER I and II & $\begin{array}{l}\text { ambassadors and their } \\
\text { deputies }\end{array}$ & ormative persuasion \\
\hline Level III - working & $\begin{array}{l}\text { teams and working } \\
\text { committees }\end{array}$ & $\begin{array}{l}\text { experts, specialists, } \\
\text { professionals }\end{array}$ & role playing \\
\hline
\end{tabular}

Source: author's own elaboration.

The behaviour of the officials according to the logic of appropriateness is therefore most evident on the working level and on the coordinating level in the intra-institutional stratification. Additionally, it is practically on these levels that the main decisions concerning a legal act are made, as it is later only that it is approved on the political level with (B Points) or without (A Points) ${ }^{23}$ discussion. Therefore, the essence of the appropriate behaviour in the environment (community) of a given official in the Council is Europeanisation via socialisation. This means that due to the social environment in which an official operates (accepting norms which apply in this environment), they are subjected to quicker (working and coordinating level) or slower (political level) Europeanisation ad personam $^{24}$, which consists in acquiring standards of operations (talks, delibera-

22 For more on Europeanisation on this level, see: Ruszkowski, 2014, p. 111.

23 Without discussion means that these points may be taken over by other compositions of the Council (usually deliberating earlier) than those which in terms of "fields" (contents) should be responsible for them.

24 It is difficult to apply Europeanisation types known in European studies literature to the officials of the EU institutions who reside outside their native state permanently or for an extended 
tions, compromise) and European values (solidarity, cooperation, and so on) by those officials in the EU institutions. Therefore, Europeanisation is a wider process than socialisation, and thus more exogenous, while socialisation is, in comparison, a process which takes place in a narrower endogenous context (in a given institution), conductive to internalisation of rules. Ad personam Europeanisation "feeds itself" on socialisation and supports it (and, conversely, a certain kind of feedback may be observed here), whereas socialisation may be Europeanisation ad personam or may cause it (as well as Europeanisation may determine socialisation).

In case of the Council of the European Union, the analysis shows that the officials on the third (working) level in the intra-institutional stratification socialise and, as a result, Europeanise quicker, while ministers on the first (political) level do it slower. Officials on the second (coordinating) level are susceptible to the Europeanisation process more than ministers, but less than experts in the working teams and committees.

What follows from the above is the fact that not every type of socialisation is Europeanisation ad personam (for instance, socialisation of the officials working in the Secretariat of the United Nations will not be Europeanisation ad personam), but every Europeanisation ad personam is "a peculiar socialisation", which in turn is a result of behaviour in accordance with the logic of appropriateness (March \& Olsen, 2010, pp. 160-168). “A peculiar socialisation" de facto signifies Europeanising (or, more precisely, Euroising) socialisation, determined by the process of European integration, with the EU as its key project.

A comparison of constructivist socialisation and Europeanisation ad personam indicates some rather important similarities between these two processes. Above all, both processes are of a social nature and that determines all other

period of time. Top-down Europeanisation concerns the impact of the European integration (or, more narrowly understood, the EU) on the member states and their political, legal and economic systems, etc., that is, from "top" to "bottom". Bottom-up Europeanisation is a process of an opposite trajectory, that is, one which concerns Europeanisation of elements constituting member states (or regions) as a result of transfer of proposals, solutions and responsibilities to the EU, from "bottom" to the "top". The outer trajectories of Europeanisation, too, such as ad extra, that is, influencing third states not belonging to the EU and international organisations, ad intra as an opposite kind of influences, that is, one of the third states and international organisations on the EU, extending and determining its mobilization and activity, are not adequate to Europeanisation of the officials of the EU institutions (Ruszkowski, 2013b, pp. 49-52). This is why the attempt to reflect the essence of the strongly personalized impact of the European integration on its officials in the EU institutions as Europeanisation ad personam is so crucial. 


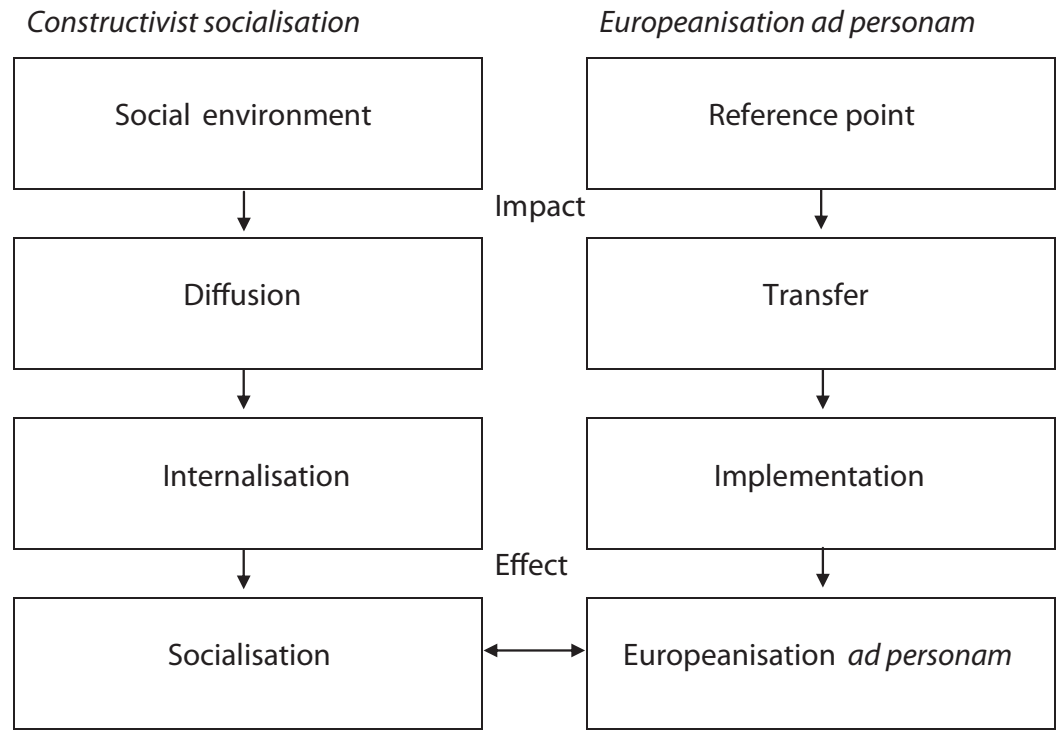

Figure 2. The Process of Socialisation and Europeanisation ad personam: A Comparison

Source: author's own elaboration.

analogies between them. Constructivist social environment, which impacts (influences) socialisation process, is an equivalent of the reference point (référentiel) in Europeanisation, which is the European Union and its institutions (or internal structures of these institutions). Constructivist diffusion of the behaviour models, values and norms of a given institution is very similar to the transfer of elements of institutional culture (including culture of responsibility) in Europeanisation. Constructivist internalization is (at least in assumption) close to the implementation (adaptation, absorption) of models and rules in Europeanisation. Finally, the effect, that is, constructivist socialization (Figure 2 is a consequence of Figure 1, hence such an order) and Europeanisation ad personam are practically the same, although the rule has to be born in mind which says that each Europeanisation ad personam is socialisation, but not every socialisation is Europeanisation. Of course, EAP of the first degree is a more intense and more effective socialisation than one which occurs in EAP of the second, third and fourth degrees, because the Europeanisation power of the EU institutions is stronger than that of the institutions outside the EU (which may 
be observed on the example of the speed of "learning" and role playing, in a form of mimicry, or in the behaviour of the officials from the EU institutions). Such powerful impact must have an influence on the political or technocratic identity of the officials.

After having conducted the analysis of the phenomenon of the Europeanisation of the first degree one cannot forget, however, that EAP of the second degree affecting the elites and citizens in the nation states ${ }^{25}$ is equally interesting (although it was not the focus of this analysis). Generally, interactions, e.g., between the (political, economic, social) elites operating in the member states, evoked by the European integration, may also be observed. These interactions are of a cognitive and normative nature, being a process thanks to which convictions, norms and values are spread and institutionalised. The European Union may create normative frameworks for socialisation of political leaders, high-level civil servants, parliament members, political experts, lobbyists, journalists, etc., who later may evoke a change of political paradigms, ideas, authorities and their legitimisation in their countries. This body of leaders may be transformed into new elites with Europeanised outlooks, behaviours, values, interests, etc. These elites may be joined by new leaders, e.g., technocrats supported by the EU regulations. Under the influence of the ad personam Europeanisation the elites are transformed, and so is their identity ${ }^{26}$. Undoubtedly, Europeanisation ad personam consolidates the technocratic approach in political activities. New technocrats on the national level, due to political competences and legitimisation provided by the EU (and its sector policies), may act as proponents of the new political order, in which new types of activities, discussions and legitimations will take place. In turn, new elites may become mediators (mediateurs) of the new, dominating reference point (référentiel) ${ }^{27}$. What it means in the research on the process of Europeanisation with the use of constructivist tools has been demonstrated above.

25 This type of Europeanisation obviously has features of top-down Europeanisation, but it is aimed at persons, so it has a strong social character. It may even be called top-down ad personam Europeanisation (this phrase, however, cannot be used in the case of ad personam Europeanisation of the first degree).

26 It must be remembered that, e.g., in the perspective of neofunctionalism, the elites behave rationally and follow the logic of consequences.

27 When mentioning elites or new elites, one has to take into account the fact that elites appear on many levels (supranational, national, regional), and interactions between elites may have not only horizontal (single-level) character, but also vertical one, that is, multi-level. One may then speak of multi-level elites (Radaelli \& Pasquier, 2007, pp. 43-44). 
These constitute (or may constitute) the results of EAP of the second degree, which here have been only signalled and require more research (as EAP of the third and fourth degrees do). Yet, this short reference to EAP of the second degree was not random, as it showed that Europeanisation ad personam may lead to various effects depending on the level of EAP. For this reason, socialisation, as an effect of Europeanisation, is also gradable.

\section{CONSTRUCTIVISM OR SOCIAL FUNCTIONALISM IN THE AD PERSONAM EUROPEANISATION STUDIES?}

The foundations of the research on Europeanisation processes may be found in functionalism, and particularly in neofunctionalism, in which both the spill-over effect, (theoretically) correlating with the transfer of elements of the institutional culture, as well as stressing the role of non-state actors (including institutions and their officials) may be supported by contemporary Europeanisation studies. David Mitrany attempted to elucidate the transfer of values, as well as social processes of various degree of complication, behaviour management and social needs. If transfers within the framework of Europeanisation processes (irrespectively of their trajectories) include (formal and informal) norms, values, models, etc., then one may speak of some theoretical connections, including explanatory ones, between neofunctionalism and constructivism, which may be important for the research on Europeanisation processes.

In keeping with the research scheme of this article, one should note that in constructivism the Council of the EU is a structure (social environment) which establishes the norms of behaviour of the officials (agents) in accordance with practices, norms and rules which dominate there, that is, are accepted and replicated since its beginning (in other words, in accordance with the logic of appropriateness). On the other hand, in neofunctionalism, the Council of the EU is a non-state agent, and its officials act more in accordance with the logic of consequences. Constructivism also explains the effect of transferring from the logic of consequences to the logic of appropriateness, which appears throughout the "learning" process, mimicry and replication of particular behaviours, including role playing (see also: Skolimowska, 2013).

Constructivism discerns the transmission of institutional standards (of institutional culture) and their diffusion and internalisation among the officials, 
which leads them to their inter-institutional socialisation on many levels within the CEU. Therefore, besides the transmission of norms and their internalisation, a constructivist effect of diffusion of norms, models and values, "spilled-over" onto individuals (officials) under the influence of both institutions and other individuals may be observed in the CEU. Such mutual impact of institutions on individuals and among the officials in the CEU is a specific type of the neofunctionalist "spill-over" effect, yet in the personal and identarian dimension. Inter-institutional "spill-over" mechanism in the CEU is based, on the one hand, on the spilling over of standards applying in the institution onto the individuals (officials), which emphasises stability and unchangeability of the institution, irrespectively of possible rotation of individuals, and on the other hand, on the spill-over of behavioural models from individuals to other individuals (from the CEU officials to other CEU officials), where even the possible rotation of the CEU officials does not affect the institutional culture of the environment and memory of the institution. This two-tier spill-over of standards and models illustrates inter-institutional Europeanisation ad personam, which in both cases is directed at individuals (officials), and which de facto is inter-institutional socialisation of individuals with Europeanisation effect.

Ad personam Europeanisation in the CEU shows that officials of this institution are not isolated individuals, nor are they autonomous individuals, as they have obligations towards the institution and other officials they work with (two reference points). Therefore, Europeanisation ad personam in the CEU confirms the two-tier spill-over of standards and models in an institution. The speed in which the CEU officials are converted to need ideas and values depends on the intra-institutional level on which they operate. The Council of the European Union, as a stable and multi-level institutional structure renders its officials' behaviour dependent on the stable intra-institutional rules. This is the principle of the logic of institutional stability, that is, a "strong dependence" of the actions of officials on the stability of the institution. These findings connect the explanatory elements of constructivism and neofunctionalism. In a somewhat hybrid manner, these two areas of explanation may be called social functionalism (Watanabe, 2010; Olsen, 2002; Skolimowska, 2013) (or rather, social neofunctionalism).

The correlation between constructivism and neofunctionalism is summarized in Table 2.

Neofunctionalism has perceived the importance of socialisation, particularly within the framework of emerging supranational solutions (systems) (in case of 
Table 2. Binds of Social Neofunctionalism (Connections between Constructivism and Neofunctionalism)

\begin{tabular}{|l|l|}
\hline Constructivism & Neofunctionalism \\
\hline Structure & Institutions (including NGOs) \\
\hline Agent & Officials in institutions \\
\hline Logic of appropriateness & Logic of consequences \\
\hline Diffusion of norms & Spill-over \\
\hline Socialisation & Europeanisation ad personam (socialisation) \\
\hline
\end{tabular}

Source: author's own elaboration.

the EU institutions it would be Europeanisation ad personam $\left.{ }^{28}\right)$. Participation of officials in new supranational systems allows a development of new perspectives and new definitions for this situation. Officials in institutions are particularly keen to show the spirit of cooperation and mutual understanding, which neofunctionalists called spirit de $\operatorname{corps}^{29}$.

As a result, constructivism is not the only valid theoretical approach in the research of Europeanisation ad personam; social functionalism (or social neofunctionalism), which cumulated the constructivist and neofunctionalist approach, is a more flexible and encompassing approach. In the study of Europeanisation processes, social functionalism allows to explain the effects of Europeanisation, which may be divided into voluntary or imposed, and intended (consciously planned) or unintended (unplanned), which means that it has also some predicating potential, allowing new research and finding new solutions.

28 Neofunctionalists also used the term: transgovernmental socialization in EU affair, which has a positive impact on the creation of supranationality (see: Beyers, 1998, p. 12).

29 Thereby neofunctionalists claimed that representatives of national states in European Communities socialize as European actors, and the differences between definitions of national and transnational interests are suppressed. That was the opinion, for instance, of L.N. Lindberg and S.A. Scheingold (Lindberg \& Scheingold, 1970). 


\section{CONCLUSIONS}

Adopting the term 'Europeanisation ad personam' seems justified in the research on Europeanisation of persons (including, for instance, officials in the Council of the EU), as none of the so-far known trajectories of Europeanisation is appropriate to research this phenomenon.

Ad personam Europeanisation is de facto sociological Europeanisation, at the same time being particularly conducive to be studies with the means of constructivist or social functionalist (social neofunctionalism) tools. Social phenomena of "mimicry", "learning,, "Europeanisation of language", correlated with ideational elements of institutional culture, their transfer and implementation, also occur in EAP. Therefore, the logic of appropriateness and socialisation, as analytical tools of (primary social) constructivism become extremely useful in the study of Europeanisation ad personam, with the caveat that every ad personam Europeanisation is a type of socialisation, but not every socialisation is Europeanisation ad personam (or Europeanisation at all).

This attempt to assist research of ad personam Europeanisation with the use of constructivist tools (particularly the logic of appropriateness and socialisation) shows that, as institutions such as the Council of the EU are perceived as normative and collective entities, with their own identity affecting the preferences of the actors, then the connections between Europeanisation (not only ad personam) and constructivism are evident. Constructivist socialisation process can therefore be correlated to the process of Europeanisation ad personam.

Finally, mixing constitutive features of the constructivist process of socialisation, classic to the Europeans studies, with their neofunctionalist equivalents in order to examine if such a measure would help optimise explaining the process of Europeanisation ad personam has shown that there are some connections between constructivism and neofunctionalism, which may become a basis for a social functionalist approach, which offers a specific set of explanatory avenues.

\section{REFERENCES:}

Bache, I., \& Marshall, A. (2004). Europeanization and Domestic Change: A Governance. Approach to Institutional Adaptation in Britain. Queen's Papers on Europeanization, 5. Beyers, J. (1998). Where does Supranationalism Come From? Ideas Floating Through the Working Groups of the Council of the European Union. European Integration Online Papers, 2(9). DOI: 10.2139/ssrn.302730. 
Borkowski, P. (2013). Międzyrządowość w procesie integracji europejskiej. Warszawa: Aspra.

Bulmer, S. (2007). Theorizing Europeanization. In: P. Graziano, \& M.P. Vink (eds.). Europeanization: New Research Agendas (pp. 46-58). Basingstoke \& New York: Palgrave Macmillan.

Bursens, P. (2007). State Structures. In: P. Graziano, \& M.P. Vink (eds.). Europeanization: New Research Agendas (pp. 115-127). Basingstoke \& New York: Palgrave Macmillan.

Caporaso, J. (2007). The Three Worlds of Regional Integration Theory. In: P. Graziano, \& M.P. Vink (eds.). Europeanization: New Research Agendas (pp. 23-34). Basingstoke \& New York: Palgrave Macmillan.

Checkel, J.T. (2001). Social Construction and European Integration. In: T. Christiansen, K. Jørgensen, \& A. Wiener (eds.). The Social Construction of Europe (pp. 50-64). London: SAGE.

Graziano, P., \& Vink, M.P. (eds.). (2007). Europeanization: New Research Agendas. Basingstoke \& New York: Palgrave Macmillan.

Jepperson, L. (2001). The Development and Application of Sociological Neoinstitutionalism. EUI Working Papers, 5, 1-54. Retrieved from: https://pdfs.semanticscholar. org/fc44/7263540fcb48df1272927f01ef5c8da18a4a.pdf.

Kirpsza, A. (2014). Proces podejmowania decyzji w Unii Europejskiej z perspektywy konstruktywistycznego programu badawczego [doctoral thesis]. Kraków: UJ.

Ladrech, R. (1994). Europeanization of Domestic Politics and Institutions: The Case of France. Journal of Common Market Studies, 32(1), 69-88. DOI: 10.1111/j.14685965.1994.tb00485.x.

Ladrech, R. (2002). Europeanization and Political Parties: Towards a Framework for Analysis. Party Politics, 8(4), 389-403. DOI: 10.1177/1354068802008004002.

Levi-Faur, D. (2007). Regulatory Governance. In: P. Graziano, M.P. Vink (eds.). Europeanization: New Research Agendas (pp. 102-114). Basingstoke \& New York: Palgrave Macmillan.

Lindberg, L.N., \& Scheingold, S.A. (1970). Europe's Would-Be Polity: Patterns of Change in the European Community. Englewood Cliffs, NJ: Prentice-Hall.

Loužek, M. (2006). Europeizacja - termin użyteczny czy tylko modny? Międzynarodowy Przegląd Polityczny, 13.

March, J.G., \& Olsen, J.P. (2010). Rediscovering Institutions: The Organizational Basis of Politics. New York: Free Press.

Mazurkiewicz, P. (2001). Europeizacja Europy. Tożsamość kulturowa Europy w kontekście procesów integracji. Warszawa: Fundacja ATK.

North, D. (1990). Institutions, Institutional Change, and Economic Performance. Cambridge: Cambridge University Press.

Olsen, J. (2002). The Many Faces of Europeanization. Journal of Common Market Studies, 40(5), 921-952. DOI: 10.1111/1468-5965.00403.

Parsons, T. (1964). Social Structure and Personality. New York: The Free Press of Glencoe. 
Peters, B.G. (1998). The New Institutionalism and Administrative Reform: Examining Alternative Models. Estudio Working Paper, 113, 1-28.

Radaelli, C.M. (2003). The Europeanization of Public Policy. In: K. Featherstone, \& C.M. Radaelli (eds.). The Politics of Europeanization (pp. 27-56). Oxford: Oxford University Press. DOI: 10.1093/0199252092.003.0002.

Radaelli, C., \& Pasquier, R. (2007). Conceptual Issues. In: P. Graziano, \& M.P. Vink (eds.). Europeanization: New Research Agendas (pp. 35-45). Basingstoke \& New York: Palgrave Macmillan.

Risse, T., Cowles, M.G., \& Caporaso, J. (2001). Europeanization and Domestic Change: Introduction. In: M.G. Cowles, J. Caporaso, \& T. Risse (eds.). Transforming Europe: Europeanization and Domestic Change (pp. 1-20). Ithaca-New York-London: Cornell University Press.

Ruszkowski, J. (2008). Zastosowanie teorii PAT do analizy wielopoziomowego zarządzania w UE. Studia Europejskie, 4, 119-141.

Ruszkowski, J. (2010a). Ponadnarodowość w systemie politycznym Unii Europejskiej. Warszawa: Wolters Kluwer.

Ruszkowski, J. (2010b). Prezydencja jako mechanizm koordynujący wewnątrz Unii Europejskiej. Znaczenie Otwartej Metody Koordynacji. In: R. Riedel, \& P. Klimontowski (eds.). 2011 - Polska prezydencja w Unii Europejskiej. Opole: Wydawnictwo Uniwersytetu Opolskiego.

Ruszkowski, J. (2012). Teorie specjalistyczne w studiach europejskich. In: J. Ruszkowski, \& L. Wojnicz (eds.). Teorie $w$ studiach europejskich. W kierunku nowej agendy badawczej (pp. 17-29). Szczecin-Warszawa: Instytut Politologii i Europeistyki Uniwersytetu Szczecińskiego, Instytut Europeistyki Uniwersytetu Warszawskiego.

Ruszkowski, J. (2013a). Neoinstytucjonalne podejście do prezydencji w Radzie Unii Europejskiej. In: R. Podgórzańska, \& D. Kowalewska (eds.). Polska w Unii Europejskiej. Wyzwania, możliwości, ograniczenia (pp.9-27). Toruń: Wydawnictwo Adam Marszałek.

Ruszkowski, J. (2013b). Struktura wielopoziomowego zarządzania w Unii Europejskiej. In: J. Ruszkowski, \& L. Wojnicz (eds.). Multi-level Governance w Unii Europejskiej (pp. 19-61). Szczecin-Warszawa: Instytut Politologii i Europeistyki Uniwersytetu Szczecińskiego, Instytut Europeistyki Uniwersytetu Warszawskiego.

Ruszkowski, J. (2014). Przyczyny ponadnarodowej aktywności Rady Unii Europejskiej: próba teoretycznego wyjaśnienia paradoksu. In: A. Wojtaszczyk, M. Mizerska-Wrotkowska, \& W. Jakubowski (eds.). Polska w procesie integracji europejskiej. Dekada doświadczeń (2004-2014) (pp. 111-134). Warszawa: Wydział Dziennikarstwa i Nauk Politycznych UW.

Skolimowska, A. (2013). Konstruktywizm w studiach europejskich. Warszawa: Oficyna Wydawnicza Łośgraf.

Trzaskowski, R. (2005). Dynamika reformy systemu podejmowania decyzji w Unii Europejskiej. Warszawa: „Prawo i Praktyka Gospodarcza”: Centrum Europejskie Natolin. 
Trzebiatowski, J. (2012). Klasyczne koncepcje socjalizacji. Socjologia wobec fenomenu „stawania się” osobowości. Kultura i Historia, 22(1).

Watanabe, L. (2010). Securing Europe: European Security in an American Epoch. Basingstoke-New York: Palgrave Macmillan.

Wendt, A. (2003). Social Theory of International Politics. Cambridge: Cambridge University Press.

Weyland, K. (2009). The Diffusion of Revolution: '1948' in Europe and Latin America. International Organization, 63(3), 391-423. DOI: 10.1017/S0020818309090146.

Zamęcki, Ł. (2011). Społeczne podstawy ładu politycznego. Warszawa: Wydział Dziennikarstwa i Nauk Politycznych UW. 